\title{
Brazilian cerrado antioxidant sources: cytotoxicity and phototoxicity in vitro
}

\author{
Fontes de antioxidantes do cerrado brasileiro: citotoxicidade e fototoxicidade in vitro
}

\author{
Roberta ROESLER ${ }^{1 *}$, Márcio LORENCINI², Gláucia PASTORE ${ }^{1}$
}

\begin{abstract}
Annona crassiflora (araticum), Eugenia dysenterica (cagaita), and Caryocar brasiliense (pequi) are tropical fruits of the second biggest Brazilian biome: the cerrado. Nowadays, the cerrado faces two different realities: 1) the great possibility of food production since it is considered as the biggest storehouse of the world; and 2) the rich biodiversity that has been newly discovered and known. Previous studies showed that certain cerrado fruits demonstrate high content of total phenols and excellent antioxidant activity in in vitro models. Moreover, using fingerprinting analysis, important bioactive molecules were identified as probably responsible for their antioxidant activity. In this study, the cytotoxicity and phototocixity of ethanolic extracts from cerrado fruits were evaluated using the in vitro Neutral Red Uptake (NRU). Regarding cytotoxicity, the extracts of araticum peel and cagaita seed did not shown any cytotoxic potential up to $300 \mu \mathrm{g} \cdot \mathrm{mL}^{-1}$. Ethanolic extracts of araticum seed

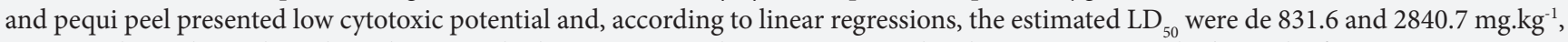
respectively. In the evaluated conditions, only the araticum peel extract presented a phototoxic potential. This is the first attempt to screen the toxicity of cerrado fruits with high antioxidant activity.

Keywords: tropical fruits; cerrado; antioxidant activity; 3 T3 neutral red uptake; cytotoxicity; phototoxicity.
\end{abstract}

\section{Resumo}

Annona crassiflora (araticum), Eugenia dysenterica (cagaita) e Caryocar brasiliense (pequi) são frutas do segundo maior bioma brasileiro: o cerrado. Atualmente, o cerrado enfrenta duas realidades diferentes: 1) a grande possibilidade de produção de alimentos, sendo considerado o maior celeiro do mundo; e 2) a riquíssima biodiversidade recentemente descoberta e conhecida. Estudos prévios demonstraram que algumas frutas do cerrado possuem alto conteúdo fenólico e excelente atividade antioxidante em modelos in vitro. Adicionalmente, por meio de análises de fingerprinting, importantes moléculas bioativas foram identificadas como prováveis responsáveis pela atividade antioxidante. Neste estudo, foram avaliadas a citotoxicidade e a fototoxicidade dos extratos etanólicos de frutas do cerrado usando o método in vitro de Neutral Red Uptake (NRU). Em relação à citotoxicidade, os extratos de casca de araticum e semente de cagaita não apresentaram potencial citotóxico até a concentração de $300 \mu \mathrm{g}$. $\mathrm{mL}^{-1}$. Extratos etanólicos de semente de araticum e casca de pequi apresentaram baixo potencial citotóxico e por meio de regressões lineares, as $\mathrm{LD}_{50}$ estimadas foram de 831,6 e $2840,7 \mathrm{mg} . \mathrm{kg}^{-1}$, respectivamente. Nas condições avaliadas, somente o extrato de casca de araticum apresentou potencial fototóxico. Esse estudo representa a primeira abordagem para screening de toxicidade de frutos do cerrado com alto poder antioxidante.

Palavras-chave: frutas tropicais; cerrado; atividade antioxidante; 3 T3 neutral red uptake; citotoxicidade; fototoxicidade.

\section{Introduction}

The importance of the search for and exploitation of natural antioxidants, especially of plant origin, has greatly increased in recent years (JAYAPRAKASHA; RAO, 2000). Both epidemiological and clinical studies have provided evidence that phenolic antioxidants present in cereals, fruits, and vegetables are the principal contributing factors in accounting for the significant reduced incidences of chronic and degenerative diseases encountered by populations whose diet is high in the intake of these foods (SHAHIDI, 1996). Typical compounds that possess antioxidant activity include phenols, phenolic acids and their derivatives, flavonoids, tocols, phospholipids, amino acids and peptides, phytic acid, ascorbic acid, pigments, and sterols (SHAHIDI, 1996). A phenol contains an -OH group attached to a benzene ring. Many phenols exert powerful antioxidant effects in vitro, inhibiting lipid peroxidation by acting as chain breaking peroxyl radicals' scavengers. Phenols with two adjacent $-\mathrm{OH}$ groups, or other chelating structures, can also bind transition metal ions in forms poorly active in promoting free-radical reacting. Phenols can also directly scavenge Reactive Oxygen Species (ROS), such as $\mathrm{OH}, \mathrm{ONOOH}$, and $\mathrm{HOCl}$ (HALLIWELL; GUITTERIDGE, 1999).

Annona crassiflora (araticum), Eugenia dysenterica (cagaita), and Caryocar brasiliense (pequi) are tropical fruits of the second biggest biome of Brazil: the cerrado. Although these fruits are highly used by traditional herbal medicine such as herbal healing, there are few scientific studies on the relationship between the biological activities and the ethnobotanical uses in order to validate them. Our previous studies show that ethanolic extracts of these fruits demonstrated high content

Recebido para publicação em 25/11/2008

Aceito para publicação em 8/7/2009 (003912)

${ }^{1}$ Laboratório de Biotecnologia Alimentar, Departamento de Ciências dos Alimentos, Faculdade de Engenharia de Alimentos, Universidade Estadual de Campinas -

UNICAMP, Rua Monteiro Lobato, n. 80, Barão Geraldo, CP 6121, CEP 13083-862, Campinas - SP, Brasil, E-mail: roesler_rr@hotmail.com

${ }^{2}$ Laboratório de Imunologia Celular do Departamento de Microbiologia e Imunologia, Instituto de Biologia, Universidade Estadual de Campinas- UNICAMP, Campinas - SP, Brasil

${ }^{*}$ A quem a correspondência deve ser enviada 
of total phenols and excellent antioxidant activity using the in vitro model 2,2-diphenyl-1-picrylhydrazyl (DPPH) and chemically induced lipid peroxidation using rat liver microsome as oxidative substrate. The best results were found for ethanolic extracts of pequi peel, cagaita seed, araticum seed, and araticum peel. The $\mathrm{IC}_{50}$ results were in the range of 14 to $50 \mu \mathrm{g} \cdot \mathrm{mL}^{-1}$ for DPPH assay and 0.7 to $4.5 \mu \mathrm{g} \cdot \mathrm{mL}^{-1}$ in the lipid peroxidation model. The use of direct infusion electrospray ionization mass (ESI-MS) and tandem Mass Spectrometries (MS) revealed the presence of important bioactive molecules in the cerrado fruit extracts, probably responsible for their antioxidant activity, such as ascorbic acid, gallic acid, quinic acid, dicaffeoylquinic acid, quercetin, quercetin 3-O-arabinose, ferulic acid, rutin, xanthoxylin, caffeic acid, and its derivatives such as caffeoyltartaric acid and caffeoyl glucose (ROESLER et al., 2006, 2007a, b).

In order to ensure that all potentially hazardous products, especially new substances, have proper warning labels and use, regulatory agencies require determination of acute toxicity hazard potential of substances and products. This determination is currently made using a test that requires laboratory rats. Historically, lethality estimated by the dose of a substance that produces $50 \%$ of animal death $\left(\mathrm{LD}_{50}\right)$ has been the primary toxicological endpoint in acute toxicity tests. The conventional $\mathrm{LD}_{50}$ acute oral toxicity in vivo test method has been modified in various ways to reduce and refine animal use in toxicity testing (ORGANISATION..., 2001; ENVIRONMENTAL..., 2002). In vitro cytotoxicity methods have been evaluated as other means to reduce and refine the use of animals, and these methods may be helpful in predicting in vivo acute toxicity. Since moving the starting dose closer to the $\mathrm{LD}_{50}$ reduces the number of animals necessary for the acute oral systemic toxicity test, the use of in vitro cytotoxicity assays to predict a starting dose close to the $\mathrm{LD}_{50}$ may reduce animal use. The Interagency Coordinating Committee on the Validation of Alternative Methods (ICCVAM) and the National Toxicology Program (NTP) Interagency Center for the Evaluation of Alternative Toxicological Methods (NICEATM) recommended further evaluation of the use of in vitro cytotoxicity data as one of the factors used to estimate the starting dose for in vivo acute lethality studies based on the preliminary information that this approach could reduce the number of animals used in in vivo studies (i.e., reduction), minimise the number of animals that receive lethal doses (i.e., refinement), and avoid underestimating hazard (NATIONAL INSTITUTE..., 2001).

Cytotoxicity has been defined as the adverse effects resulting from the interference with structures and/or processes essential for cell survival, proliferation, and/or function (EKWALL, 1983). Other researchers (GRISHAM; SMITH, 1984) also concluded that since the actions of substances that produce injury and death are ultimately exerted at cellular level in vitro cytotoxicity assays may be useful for the prediction of acute lethal potency. The endpoint measured in the in vitro Neutral Red Uptake (NRU) cytotoxicity test is cell viability and the major endpoint of interest is the half maximal inhibitory concentration, i.e. the concentration which promotes $50 \%$ of inhibition in the NRU $\left(\mathrm{IC}_{50}\right)$.
The dermal phototoxicity of a chemical is defined as a toxic response that is elicited after the exposure of skin to a chemical or systemic administration of a chemical and subsequent exposure to Ultraviolet (UV) light. As demonstrated by several validation studies (BORENFREUND; PUERNER, 1985; CENTRE...; EUROPEAN...; THE EUROPEAN..., 2000; NATIONAL INSTITUTE..., 2001), the phototoxic potential of chemicals can be effectively assessed by in vitro methods. In 1991, the European Commission (EC), initially represented by the Directorate General XI and later by the European Centre for the Validation of Alternative Methods (ECVAM) and the European Cosmetic, Toiletry and Perfumery Association (COLIPA), agreed to establish a joint EU/COLIPA programme on the development and validation of in vitro phototoxicity tests. In 1996, the Organisation for Economic Co-operation and Development (OECD) recommended an in vitro tier-testing approach for phototoxicity assessment (SPIELMANN et al., 1998). In 2000, the Commission of European Communities put into force the Directive 200033EC, which introduces the in vitro 3T3 NRU phototoxicity test as a validated replacement for testing methods involving the use of laboratory animals. The essence of this test is to compare the cytotoxicity of a chemical when tested in the presence and absence of exposure to a non-cytotoxic dose of ultraviolet A (UVA) light (PETERS; HOLZHUTTER, 2002).

The aim of this study is to evaluate the toxicity of the Brazilian cerrado fruit extracts by using the in vitro 3T3 NRU cytotoxicity and phototoxicity methods in order to estimate the applicability of these fruits as a sustainable source of natural antioxidant for cosmetic, foods, and pharmaceutical applications.

\section{Materials and methods}

\subsection{Cell lines}

BALB/C 3T3 mouse fibroblasts, clone 31, were obtained from ATCC (Manassas, VA, USA).

\subsection{Chemicals and media}

Dulbecco's Modified Eagle Medium (DMEM) (Gibco, Grand Island - NY, USA), Phosphate Buffered Saline (PBS), NR dye (Sigma-Aldrich, Saint Louis, MO, USA), New Born Calf serum (NBCS) (Nutricell, Campinas - SP, BR), ethanol (Synth, Diadema - SP, BR), acetic acid glacial (Carlo Erba, Rodano, MI, IT), sodium lauryl sulphate (positive control for cytotoxicity) (Sigma-Aldrich, Saint Louis, MO, USA), and chlorpromazine (positive control for phototoxicity) (Sigma-Aldrich, Saint Louis - MO, USA).

\subsection{Plant material}

Annona crassiflora (araticum), Eugenia dysenterica (cagaita), and Caryocar brasiliense (pequi) were selected based on the traditional application and lack of information related to acute toxicity (Table 1). They were obtained from Erlow Farm, Km 07 Br 070, Goiânia, Center West Brazil. Fruit harvests were conduced twice and special care was taken to avoid damaging the fruits. The fruits were transported to the State University of Campinas - UNICAMP and stored at $5{ }^{\circ} \mathrm{C}$ until use for two months maximum. 
Table 1. Ethnobotanical data of selected cerrado fruits.

\begin{tabular}{|c|c|c|c|c|}
\hline Specie & Family & Local name & Portion used & Traditional uses \\
\hline Annona crassiflora & \multirow[t]{2}{*}{ Annonaceae } & \multirow{2}{*}{$\begin{array}{l}\text { Araticum, Marolo, } \\
\text { Cabeça de negro }\end{array}$} & Seed & Snake bite $^{(1)}$, hair antiparasitic ${ }^{(2)}$ \\
\hline Annona rodriguesii & & & Seed, leaves & Antidiarrhea $^{(2,3)}$ \\
\hline \multirow{2}{*}{$\begin{array}{l}\text { Eugenia dysenterica } \\
\text { Stenocalyx sp. }\end{array}$} & \multirow[t]{2}{*}{ Myrtaceae } & \multirow[t]{2}{*}{ Cagaita } & Fruits & Lexative $^{(2)}$ \\
\hline & & & Leaves & Antidiarrhea $^{(2)}$ \\
\hline \multirow[t]{3}{*}{ Caryocar brasiliense } & \multirow[t]{3}{*}{ Caryocaraceae } & \multirow[t]{3}{*}{ Pequi, piqui, piquia } & Nut oil & $\begin{array}{l}\text { Asthma, influenza, cold, } \\
\text { bronchopulmonary diseases }{ }^{(2,3)}\end{array}$ \\
\hline & & & Seed & Aphrodisiac tonic ${ }^{(3)}$ \\
\hline & & & Leaves & Regulation of women period ${ }^{(2)}$ \\
\hline
\end{tabular}

These data was based on 1) Weinberg et al. (1993); 2) Almeida et al. (1998); and 3) Rodrigues e Carvalho (2001).

\subsection{Ethanolic extraction}

Undamaged fruits were selected and peeled, and the pulp and seeds were manually separated. About $100 \mathrm{~g}$ of each part was cut in small fragments, mixed, and extracted twice with $300 \mathrm{~mL}$ of aqueous ethanol (5:95, v/v, water: ethanol) using a household mixer for 20 minutes. The extracts were filtered through a cotton membrane and the residue was re-extracted under the same conditions. The residues were kept for further evaluations. The resultant material was subjected to vacuum rotary evaporation at $40^{\circ} \mathrm{C}$ to remove ethanol. The concentrated ethanolic extracts were lyophilised and stored at $-18^{\circ} \mathrm{C}$ in amber glass bottles until use.

\subsection{In vitro cytotoxicity}

The assays were carried out according to the official protocol from OECD (ORGANISATION..., 2001). Briefly, 3 T3 cells were seeded into 96-well plates to form a sub confluent monolayer $\left(1 \times 10^{4}\right.$ cells/well $)$. The culture medium was removed and different concentrations of test chemicals in medium were added to cells for 48 hours, $37^{\circ} \mathrm{C}, 5 \% \mathrm{CO}_{2}$. The untreated vehicle control was the same as the treatment medium. The cells were washed once with PBS, and NR dye medium was added for 3 hours, $37^{\circ} \mathrm{C}, 5 \% \mathrm{CO}_{2}$. The cells were washed with PBS, and NR desorb solution (50:1:49, v/v/v, ethanol: acetic acid: water) was added to the plates. The plates were shaken for 20 minutes and NR absorption was measured at Optical Density (OD) $540 \pm 10 \mathrm{~nm}$. Cell viability was calculated as the percentage of control values to define $\mathrm{IC}_{50}$ substance concentrations $\left(\mu \mathrm{g} \cdot \mathrm{mL}^{-1}\right)$ (NATIONAL TOXICOLOGY..., 2003, 2006).

\subsection{In vitro phototoxicity}

The assays were performed according to the official protocol from NIH (NATIONAL INSTITUTE..., 2001). Briefly, the cells were prepared as in the cytotoxicity protocol considering two plates for each test sample. The 3T3 NRU test for phototoxicity requires a 60 -minute exposure to sample dilutions in PBS followed by UVA ( $5 \mathrm{~J} . \mathrm{cm}^{-2}$ ) exposure of one of the plates (the other plate is used as non irradiated control). After washing both plates with PBS, the cells were incubated for 24 hours, $37^{\circ} \mathrm{C}, 5 \% \mathrm{CO}_{2}$. The plates were washed, incubated with NR dye medium, and re-washed. The NR desorb solution was added and $\mathrm{NR}$ absorption was measured at OD $540 \pm 10 \mathrm{~nm}$. Cell viability was calculated for each treatment. Phototoxicity was assessed by comparing the differences in toxicity between negative control plates that had not been exposed to UVA and test plates exposed to UVA. The Photo-Irritancy Factor (PIF) relates the halfeffective concentration values $\left(\mathrm{EC}_{50}\right)$ of the curve for darkness $\left(\mathrm{EC}_{50}[-\mathrm{UV}]\right)$ and in the presence of light $\left(\mathrm{EC}_{50}[+\mathrm{UV}]\right)$ by means of the following equation (Equation 1):

$\mathrm{PIF}=\mathrm{EC}_{50}[-\mathrm{UV}] / \mathrm{EC}_{50}[+\mathrm{UV}]$

Depending on whether the PIF value is larger or smaller than the cut-off value of five units, the chemical is classified as phototoxic or non-phototoxic, respectively. A shortcoming of the measure in Equation 1 is that additional ad hoc definitions are required to cope with situations in which no $\mathrm{EC}_{50}$ values can be derived from the corresponding concentration-response curve: 1) if no $\mathrm{EC}_{50}$ value can be derived from one of the curves, the corresponding $\mathrm{EC}_{50}$ value in Equation 1 is replaced by the highest concentration tested, and the chemical is classified as phototoxic if this modified PIF value is larger than one unity; and 2) if no $\mathrm{EC}_{50}$ value exists for both curves, the chemical is considered non-phototoxic (Borenfreund; Puerner, 1985; CENTRE...; EUROPEAN...; THE EUROPEAN..., 2000; NATIONAL INSTITUTE..., 2001).

A second measurement of the difference between the dark and light curve, the so-called Mean Photo Effect (MPE), was proposed by Holzhütter (1997). It aims to overcome the obvious limitations in the application of the PIF by comparing the two curves at arbitrary doses, and it is useful even in situations where no $\mathrm{EC}_{50}$ values can be derived from the corresponding concentration-response curve. The MPE measures the effect of UV exposure over a range of concentrations. A material is considered non-phototoxic if the MPE is $<0.1$ and phototoxic if the MPE is $\geq 0.1$.

\subsection{Data analysis}

Both measures of curve difference, PIF and MPE, represent statistical estimates that have to be derived from the observed concentration-response relations. To facilitate this work and to harmonise the process of data analysis, the software PHOTOTOX 2.0 (ZEBET, Diedersdorfer, BE, DE) was used. This program module performs a bootstrap resampling of the original concentration-response data that result in a set of new computer-generated concentration-response data (100 times), which can be considered as equally probable realisations of the "true" concentration-response data hidden in the experimental observations. Based on these curves, and at given cut-off values, the program calculates PIF and MPE, and determines the probability ( $\mathrm{p}$-value) that a test chemical is phototoxic (PETERS; HOLZHÜTTER, 2002). 


\subsection{Prediction of $L D_{50}$}

To obtain a model for the prediction of lethal dose $\mathrm{LD}_{50}$ values from $\mathrm{IC}_{50}$ values, Halle (2003) calculated a linear regression from pairs of the log-transformed $\mathrm{IC}_{50}$ (in $\mathrm{mM}$ ) and log transformed rodent oral $\mathrm{LD}_{50}$ values (in mmol. $\mathrm{kg}^{-1}$ ). Equation 2, which was obtained from a correlation between values of in vitro cytotoxicity and rat and mouse oral $\mathrm{LD}_{50}$ values for 347 chemicals, is:

$\log \mathrm{LD}_{50}\left(\mathrm{mmol} \cdot \mathrm{kg}^{-1}\right)=0.435 \times \log \mathrm{IC}_{50 \mathrm{x}}(\mathrm{mM})+0.625$

This Equation was denominated RC regression. Presumably, the substance units were expressed in moles because these are units that produce biological activity and, hence, they are expected to produce the best fitting regression. $\mathrm{IC}_{50}$ values for 347 substances were obtained from 157 original publications (HALLE, 2003). The $1912 \mathrm{IC}_{50}$ values, two to 32 per substance, were averaged using geometric means to produce one $\mathrm{IC}_{50 x}$ value for each substance.

To improve the $\mathrm{RC}$ regression in terms of the prediction of $\mathrm{LD}_{50}$ values by in vitro NRU $\mathrm{IC}_{50}$ values, some regressions were developed using RC data in weight units to excluding: 1) mouse data (i.e. RC rat-only regression); and 2) substances with mechanisms of toxicity that were not expected to be active in the 3T3 cell cultures (i.e. RC rat-only regression excluding substances with specific mechanisms of toxicity) (NATIONAL TOXICOLOGY..., 2006).

Equation 3 for the RC rat-only weight regression is:

$\log \mathrm{LD}_{50}\left(\mathrm{mg} \cdot \mathrm{kg}^{-1}\right)=0.372 \times \log \mathrm{IC}_{50}\left(\mu \mathrm{g} \cdot \mathrm{mL}^{-1}\right)+2.024$

Equation 4 for the RC rat-only weight regression excluding substances with specific mechanisms of toxicity is:

$\log \mathrm{LD}_{50}\left(\mathrm{mg} \cdot \mathrm{kg}^{-1}\right)=0.357 \times \log \mathrm{IC}_{50}\left(\mu \mathrm{g} \cdot \mathrm{mL}^{-1}\right)+2.194$

\subsection{Solubility protocol}

For testing the chemicals prepared in the chemical dilution medium, the highest test article concentration that may be applied to cell in the main experiments will be either $100 \mathrm{mg} \cdot \mathrm{mL}^{-1}$ or the maximum soluble dose. For test chemicals prepared in either DMSO or ethanol, the highest test article concentration that may be applied to the cells in the major experiments will be either $2.5 \mathrm{mg} \cdot \mathrm{mL}^{-1}$ or less depending upon the maximum solubility in the solvent (NATIONAL TOXICOLOGY..., 2003, 2006).

\section{Results and discussion}

\subsection{Cytotoxicity}

NR is a weakly cationic, water-soluble dye that stains living cells by readily diffusing through the plasma membrane and concentrating in lysosomes. The intensity of the dye in the culture is directly proportional to the number of living cells. In addition, since altering the cell surface or the lysosomal membrane by a toxicological agent causes lysosomal fragility and other adverse changes that gradually become irreversible, cell death and/or inhibition of cell growth decreases the amount of NRU by culture (BORENFREUND; PUERNER, 1985).
A calculation of cell viability is expressed as NRU for each concentration of the chemical by using the mean NRU of four replicate values (blank is subtracted). These values are compared with the control mean values. Relative cell viability is then expressed as a percentage of untreated vehicle control.

Cagaita seed (Figure 1a) and araticum peel (Figure 1c) ethanolic extracts did not decrease cell viability up to $300 \mu \mathrm{g} . \mathrm{mL}^{-1}$. Thus, no significant general toxicity was observed and the $\mathrm{IC}_{50}$ values higher than $300 \mu \mathrm{g} \cdot \mathrm{mL}^{-1}$. Due to the low solubility of these fruit extracts, it was not possible to increase the concentration in order to obtain an $\mathrm{IC}_{50}$ value. Pequi peel extract was tested up to $3000 \mu \mathrm{g} \cdot \mathrm{mL}^{-1}$. At this concentration, the pequi peel extract started producing a precipitated in the cell culture medium and caused a decrease in cell viability. If the linear correlation of cell viability decrease in the PHOTOTOX program and pequi peel ethanolic extract concentration are considered, the mean $\mathrm{IC}_{50}$ would be $3731.3 \pm 579 \mu \mathrm{g} \cdot \mathrm{mL}^{-1}$ (Figure 1d). Regarding the araticum seed ethanolic extract, the results suggested some evidence of moderate toxicity, and mean $\mathrm{IC}_{50}$ value for the araticum seed ethanolic extract was $108.0 \pm 7 \mu \mathrm{g} \cdot \mathrm{mL}^{-1}$ (Figure 1b).

Using the regressions previously described, the $\mathrm{LD}_{50}$ values for the extracts were predicted. Considering Equation 3 (RC ratonly weight regression), the $\mathrm{LD}_{50}$ result obtained for the pequi peel extract was $2169.4 \mathrm{mg} \cdot \mathrm{kg}^{-1}$, and for the araticum seed extract it was $603.2 \mathrm{mg} . \mathrm{kg}^{-1}$. Using Equation 4 (RC rat-only weight regression excluding substances with specific mechanisms of toxicity), the $\mathrm{LD}_{50}$ results were 2840.7 and $831.6 \mathrm{mg} \cdot \mathrm{kg}^{-1}$ for the pequi peel and araticum seed extracts, respectively. For comparative purposes, Table 2 shows some chemicals' data regarding $\mathrm{LD}_{50}$ and $\mathrm{IC}_{50}$.

Previous studies in vivo with two groups of seven rats each showed that orally administrated aqueous solution of A. crassiflora seed extract ( $50 \mathrm{mg}$ of gallic acid equivalents per $\mathrm{kg}$, i.e. $767 \mathrm{mg}$ of crude extract per $\mathrm{kg}$ of weight) for 14 consecutive days did not produce any death, clinical signs, or gross alterations attributable to hepatic toxicity or other organ damage if compared to a control group that received saline solution until

Table 2. Values of cytotoxic potential $\left(\mathrm{IC}_{50}\right)$ by in vitro NRU and Oral $\mathrm{LD}_{50}$.

\begin{tabular}{lcc}
\hline Extract or chemical compound & $\begin{array}{c}\text { Cytotoxicity } \mathrm{IC}_{50} \\
\left(\mu \mathrm{g} \cdot \mathrm{mL}^{-1}\right)\end{array}$ & $\begin{array}{c}\mathrm{Oral} \mathrm{LD}_{50} \\
\left(\mathrm{mg}^{\mathrm{kg}}\right)^{-1}\end{array}$ \\
\hline Cagaita seed & $>300.0$ & $\mathrm{ND}$ \\
Araticum seed & $108.0 \pm 7$ & 831.6 \\
Araticum peel & $>300.0$ & $\mathrm{ND}$ \\
Pequi peel & $3731.3 \pm 579$ & 2840.7 \\
Sodium lauryl sulphate & $40 \pm 0^{(1)}$ & $\mathrm{ND}$ \\
Phenol & $50 \pm 10^{(2)}$ & $414^{(3)}$ \\
Nicotine & $270 \pm 70^{(2)}$ & $50^{(3)}$ \\
Glycerol & $24650^{(2)}$ & $12691^{(3)}$ \\
Bergamot oil & $\mathrm{ND}$ & $\mathrm{ND}^{(3)}$ \\
Caffeine & $\mathrm{ND}$ & $192^{(3)}$
\end{tabular}

The oral $\mathrm{LD}_{50}$ values were calculated for the plant extracts using the RC rat-only weight regression. The different compounds in the table are references for cytotoxic potential comparison. These data were based on 1)National Toxicology... (2006); 2)Ghs (GLOBALLY..., 2005); and 3)Halle (2003). ND: not determined. 

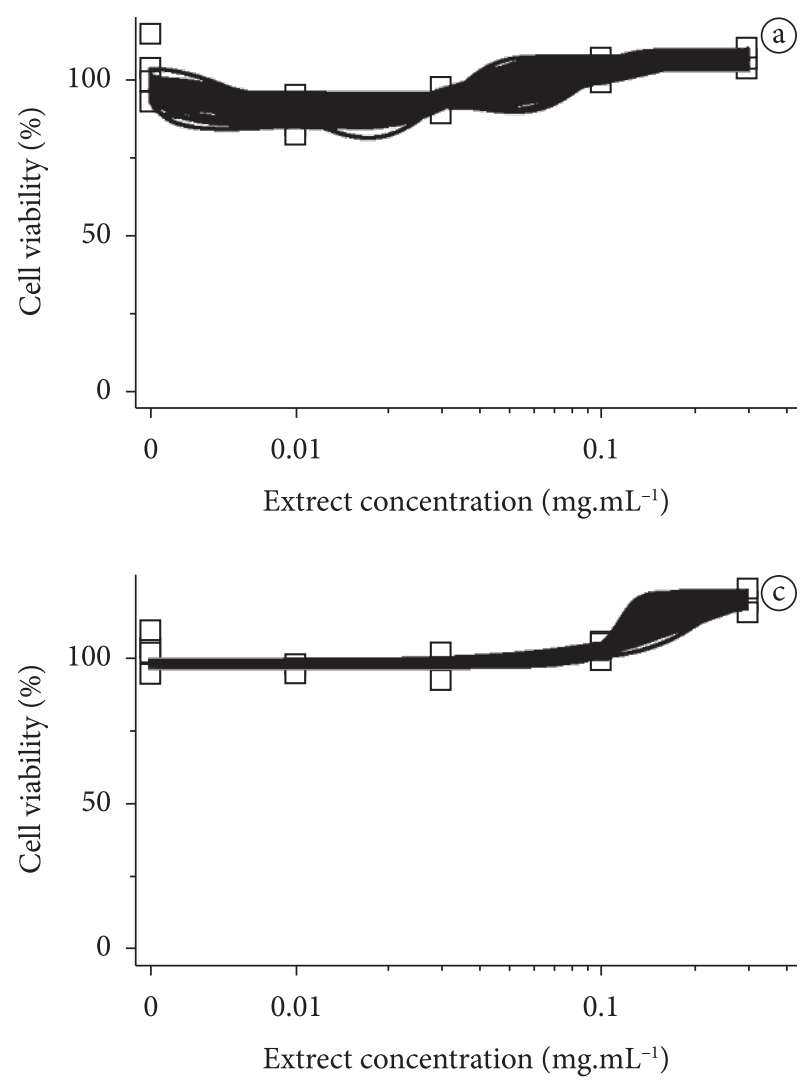
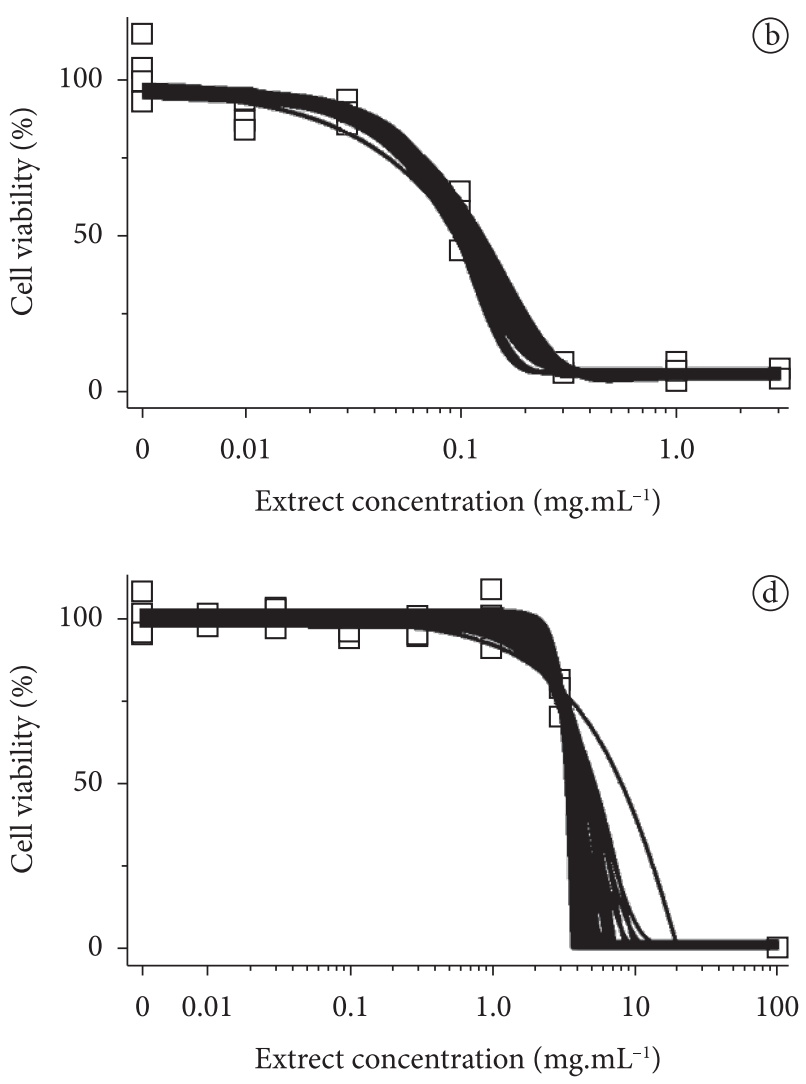

Figure 1. Cytotoxicity evaluation for the cerrado fruits extracts: a) cagaita seed; b) araticum seed; c) araticum peel; and d) pequi peel. The graphs include the original concentration-response data and the curves generated from the bootstrap analysis.

the $14^{\text {th }}$ day. However, rats that received the A. crassiflora seed extract showed some anxiety and were restless, perhaps because of the phenolic acids and their derivatives (caffeic acid, caffeoyl glucose and caffeoyl tartaric) present in this extract. In addition, it was observed that there was significant reduction in the body weight gain (approximately 28 and 23\%, respectively) of the two groups that received seed extract if compared with the control group (Roesler et al., 2007a). The same study was conducted for the A. crassiflora peel extract, in which two groups of seven rats each received an aqueous solution of $50 \mathrm{mg}$ of gallic acid equivalents per $\mathrm{kg}$ orally, i.e. $358 \mathrm{mg}$ of crude extract per $\mathrm{kg}$ of weight for 14 days. No different behaviour was observed for these two groups. Thus, the in vitro result is in agreement with the previous in vivo study once there was no sign of cell viability decrease up to the maximum concentration tested. In addition, the in vitro method was able to estimate that the A. crassiflora seed extract could be harmful since it showed moderate citotoxicity.

Considering the results obtained in vivo, it is possible that the in vitro NRU cytotoxicity test predicted the toxicity of the A. crassiflora seed extract by estimating a lower $\mathrm{LD}_{50}$ value than that necessary to produce lethal death. The endpoint measured in the in vitro NRU cytotoxicity tests is cell death, and the endpoint measured in the acute systemic toxicity assays is usually animal death. Cell death and animal death may be similar since animals are comprised of organ systems consisting of tissues, which are comprised of cells. All cells, regardless of whether they are animal cells or in vitro cell cultures, have similar cellular mechanisms of energy production, utilisation, and maintenance of cell membrane integrity. Animal death and death of cells in culture due to toxicity are similar in that both involve some type of injury. For the animals, the cellular injury leads to tissue and organ injury to the most sensitive target organ, which may then cause the death of the whole organism. An organ system failure can be due either to the death of cells in the affected organ or to the loss of function of the surviving cells in the organ, which results in cell death or loss of function in other organs (GENNARI et al., 2004). The death of an animal is a result of major organ system failure. Ultimately, the cardiovascular and respiratory systems fail. Respiratory depression may be due to the depression of the central nervous system rather than a direct assault on the respiratory system. Other major organ system failures, such as liver and kidney failure, gastrointestinal corrosion, and bone marrow depression, also cause death. Cell death is a culture system that involves the death of a single cell type. Cell death and animal death may be caused by the same mechanisms, such as disruption of membrane structure or function, inhibition of mitochondrial function, disturbance of protein turnover, and disruption of energy production etc (GENNARI et al., 2004). Animal and cell culture systems are different with respect to how a substance or 
toxin is delivered to cell, and how it is distributed, metabolised, and excreted. The 3T3 cell culture system includes serum and has little or no capacity to metabolise xenobiotic compounds. The excretion from the cell culture milieu cannot occur since cell culture systems have no excretory system. The culture cells are exposed to substances during the test system.

\subsection{Phototoxicity}

Differently from the in vitro cytotoxicity results that are used to screen toxicity and to estimate the $\mathrm{LD}_{50}$ of chemicals, the NRU phototoxicity assay using 3T3 cells was validated by ECVAM and accepted for regulatory use to detect the phototoxic potencial of substances. The phototoxic potential is assessed by comparing the differences in toxicity between negative control plates that were not exposed to UVA and test plates exposed to UVA (Figure 2).
Considering the analysis of the PIF values (Table 3), none of the extracts showed phototoxic potential in the dosage levels tested; only the pequi peel and araticum seed ethanolic extract presented cell viability reduction during the exposure to UVA light. The mean PIF obtained for the pequi peel and seed extracts were 1.0 and 1.6, respectively. Although there was cell viability reduction, it occurred even for the no exposed plates so the PIF value was relatively low and the extracts were not considered phototoxic (PIF < 5). Due to the low solubility of cagaita seed and araticum peel extracts, it was not possible to increase the concentration (it was tested up to $300 \mu \mathrm{g} \cdot \mathrm{mL}^{-1}$ ) in order to obtain the $\mathrm{EC}_{50}$ values with or without UVA radiation. Consequently, it was not possible to define their respective PIF values.

The MPE values (Table 3) were also calculated and the nonphototoxic potential was confirmed for the extracts of araticum
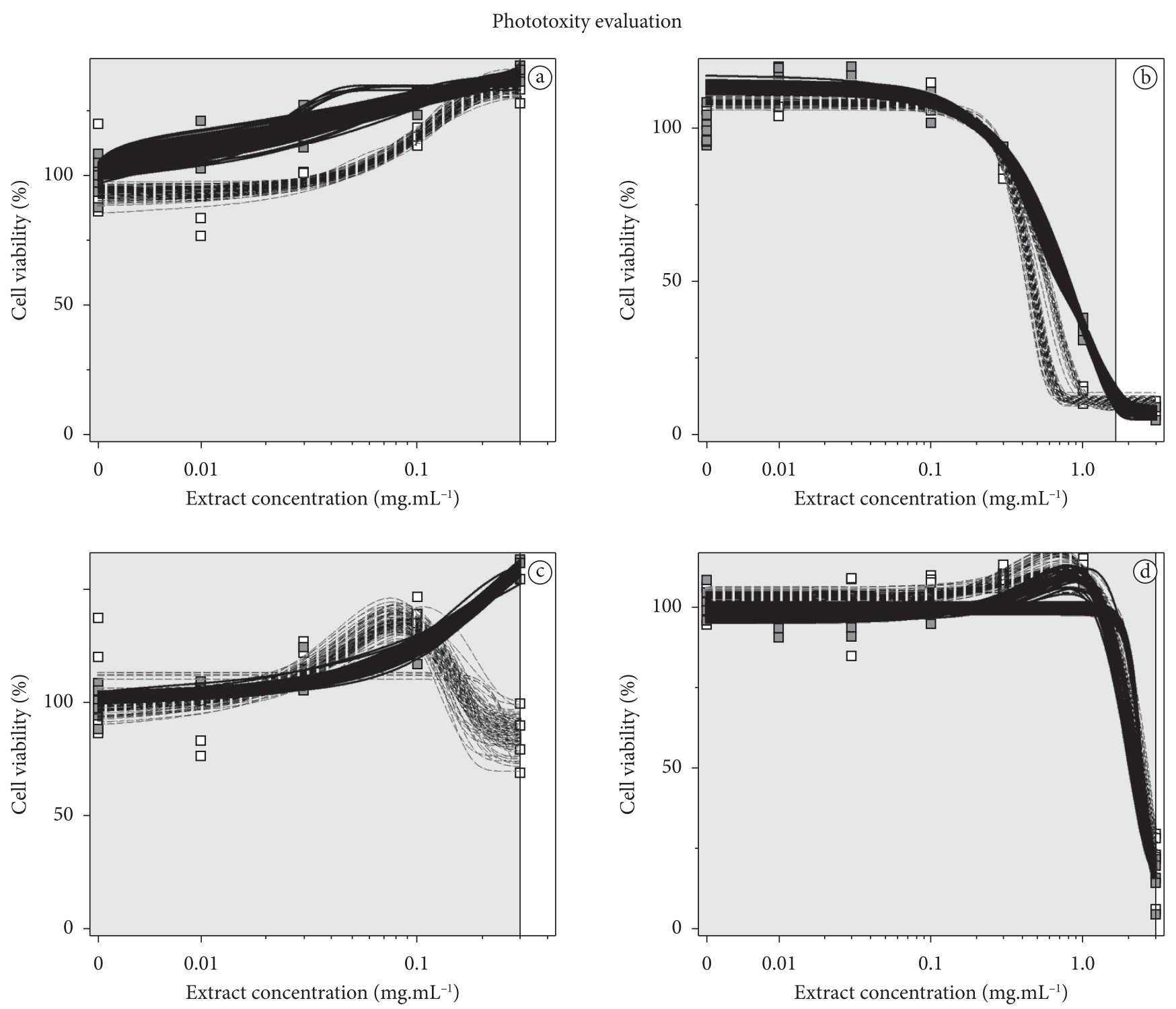

Figure 2. Phototoxicity evaluation for the cerrado fruits extracts: a) cagaita seed; b) araticum seed; c) araticum peel; and d) pequi peel. Gray and white points represent data from dark and light curves, respectively. The graphs include the original concentration-response data and the curves generated from the bootstrap analysis. 
Table 3. Values of phototoxic potential (PIF and MPE) by in vitro NRU and p values.

\begin{tabular}{|c|c|c|c|c|c|}
\hline Extract or chemical compound & In vivo & PIF & p-value $\times 100 \%$ & MPE & $\mathrm{p}$-value $\times 100 \%$ \\
\hline Cagaita seed & ND & $1.0^{*}$ & $0 \%$ & 0.09 & $21 \%$ \\
\hline Araticum seed & ND & 1.6 & $0 \%$ & 0.03 & $0 \%$ \\
\hline Araticum peel & ND & $1.0^{*}$ & $0 \%$ & 0.14 & $95 \%$ \\
\hline Pequi peel & ND & 1.0 & $0 \%$ & 0.00 & $0 \%$ \\
\hline Sodium lauryl sulphate & Not phototoxic & 1.3 & $1 \%$ & 0.01 & $0 \%$ \\
\hline Penicillin G & Not phototoxic & 3.2 & $21 \%$ & 0.09 & $29 \%$ \\
\hline Terephthalidene dicamphor s.a. & Not phototoxic & 1.6 & $63 \%$ & 0.01 & $9 \%$ \\
\hline Bergamot oil & Phototoxic & 15.2 & 0.79 & 0.37 & 0.91 \\
\hline Chlorpromazine & Phototoxic & 36.0 & $100 \%$ & 0.34 & $100 \%$ \\
\hline Furosemide & Phototoxic & 91.8 & $43 \%$ & 0.15 & $54 \%$ \\
\hline
\end{tabular}

The different compounds in the table are references for phototoxic potential comparison. These data were based on Peters and Holzhütter (2002). ND: not determined. ${ }^{\star P I F}$ was considered 1.0 because no $\mathrm{EC}_{50}$ value exists for both curves.

seed, cagaita seed, and pequi peel. However, for the araticum peel extract it was found a MPE value of 0.135 indicating a phototoxic potential that could not be predicted using PIF because of the low solubility of this extract.

Table 2 presents some chemicals PIF and MPE values for comparative purposes, and the correspondent $p$-values calculated in the PHOTOTOX software. The phototoxicity results obtained by the in vitro NRU method are of great importance especially for cosmetic and pharmaceutical application since topical formulations are commonly used during the day with exposure to the sun and artificial light.

\section{Conclusions}

Brazil has a strong tradition of herbal medicine and, like most developing countries, its rural and traditional population still depends mainly on the indigenous system of medicine for their healthy related matters. Herbal medicines are frequently used to treat a large variety of ailments and symptoms, such as fever, inflammation, and pain. However, there is little information about their efficacy and lack of acute toxicity.

The Anonnacea family has a great variety of exotic fruits, which are apparently rustic and have typical form such as sugar-apple or sweetsop (Annona squamosa), graviola (Annona muricata), and araticum of cerrado or marolo (Annona crassiflora) (SILVA; TASSARA, 2001). Many members of Anonnaceas are used in folk medicine for antiparasitic or antitumoral treatment of intestinal diseases. In Brazil, the fruits are sold in regional markets and have no commercial value. The seeds in oil are used against scalp infections and in folk medicine; the leaves and seeds infusion is used against diarrhoea and as antitumor drug (LORENZI, 1992; ALMEIDA et al., 1998). In addition, the seeds of Annona crassiflora are believed to be efficacious against snake venom. Weinberg et al. (1993) found that the hydro-alcoholic extract of Annona crassiflora seed showed a non-specific inhibitory effect on drug-induced contractions of guinea-pig ileum, which could be responsible for the effect against snake venom. Londershausen et al. (1991) showed that some annonins isolated from seeds of Annona squamosa revealed interesting insecticidal properties.

The fruits of pequi (C. brasiliense) represent an important option of income and food for the populations living in the cerrado regions of Brazil. The pulp of the pequi fruit has good quantity of edible oil, vitamin A, and proteins. On the other hand, the nut also has oil, which is applied in cosmetic products such as soaps and skin emulsions (SILVA; TASSARA, 2001). High quality yellow colour is extracted from the peel and leaf, and it is used for dying fibres. With regard to folk medicine, the pulp oil is traditionally used as a tonic agent against asthma, influenza, ordinary cold, and bronchopulmonary diseases (ALMEIDA et al., 1998; RODRIGUES; CARVALHO, 2001).

The Eugenia dysenterica is a shrubby tree with edible cherry-like fruits called cagateira (CORRÊA, 1984). The plants are well known in the Brazilian cerrado medical practices, and the leaves are part of preparations used for medical diarrhoeic care and dysentery (SEPTÍMIO, 1994). The fruits are consumed in nature with moderation, because of its laxative activity, or as homemade preparations such as juice, ice cream, and jelly (SILVA et al., 1994). The volatile constituents of the Eugenia dysenterica leaf oil has been investigated for its antifungal activity (COSTA et al., 2000).

In conclusion, the in vitro NRU methods showed that the excellent antioxidant extracts of the araticum seed, cagaita seed, and pequi peel did not present phototoxic hazard; only the araticum peel extract presented a phototoxic potential indicating that complementary studies should be carried out to evaluate the possible in vivo effects if any topical use of this extract is intended. With regard to cytotoxicity, the araticum peel and cagaita seed extracts did not show any inhibition of cell grown up to $300 \mu \mathrm{g} \cdot \mathrm{mL}^{-1}$ the maximum solubility of these extracts. The araticum seed extract presented an $\mathrm{IC}_{50}$ of $108.0 \pm 7 \mu \mathrm{g} \cdot \mathrm{mL}^{-1}$ and the pequi peel extract had an estimated $\mathrm{IC}_{50}$ of $3731.3 \pm 579 \mu \mathrm{g} \cdot \mathrm{mL}^{-1}$. The $\mathrm{LD}_{50}$ obtained by using the $\mathrm{RC}$ rat-only weight regression for the araticum seed extract was $831.6 \mathrm{mg} . \mathrm{kg}^{-1}$ and for the pequi peel extract it was $2840.7 \mathrm{mg} \cdot \mathrm{kg}^{-1}$. While the in vitro NRU phototocixity method is validated and accepted for regulatory uses, the cytotoxicity data should be used as a screening procedure to assess cytotoxicity as well as one of the factors used to estimated the starting dose for in vivo acute lethality studies based on the preliminary information that this approach could reduce the number of animals used in in vivo studies (i.e. reduction), minimize the number of animals that receive lethal doses (i.e. refinement), and avoid underestimating hazard. A detailed evaluation of tropical plants used in local 
health traditions and the ethnopharmacological evaluation to verify their efficacy and safety can lead to the development of invaluable herbal drugs or isolation of compounds of therapeutic value. It is expected that the search for an economically viable and environmentally correct application of cerrado natural resources, such as natural antioxidants, could increase the value of these fruits and help avoid the destruction of natural vegetation and cerrado biodiversity.

\section{Acknowledgements}

The authors would like to thank the Brazilian National Research Council (CNPq) for the financial support.

\section{References}

ALMEIDA, S. P. et al. Cerrado: espécies vegetais úteis. Planaltina: Empresa Brasileira de Pesquisa Agropecuária - EMBRAPA, 1998.

BORENFREUND, E.; PUERNER, J. A. Toxicity determined in vitro by morphological alterations and neutral red absorption. Toxicology Letters, v. 24, n. 2-3, p. 119-124, 1985.

CENTRE FOR DOCUMENTATION AND EVALUATION OF ALTERNATIVES TO ANIMAL EXPERIMENTS - ZEBET; EUROPEANCENTREFORTHEVALIDATIONOF ALTERNATIVE METHODS - ECVAM; THE EUROPEAN COSMETICS TOILETRY AND PERFUMERY ASSOCIATION - COLIPA. Standard Operating Procedure: In vitro 3T3 NRU phototoxicity test (OJ L 136 2000). 2000. Annex V Testing Methods.

CORRÊA, P. Dicionário das plantas úteis do Brasil e das exóticas cultivadas. Rio de Janeiro: Imprensa Nacional, 1984.

COSTA, T. R. et al. Antifungal activity of volatile constituents of Eugenia dysenterica leaf oil. Journal of Ethonopharmacology, v. 72, n. 1-2, p. 111-117, 2000.

EKWALL, B. Screening of toxic compounds in mammalian cell cultures. Annals of the New York Academy of Sciences, v. 407, p. 64-77, 1983.

ENVIRONMENTAL PROTECTION AGENCY - EPA. OPPTS Harmonized Test Guidelines. Guideline OPPTS 870.1100: Acute oral toxicity. 2002. EPA 712-c-02-190.

GENNARI, A. et al. Strategies to replace in vivo acute systemic toxicity testing. The report and recommendations of ECVAM Workshop 50. Alternative to Laboratory Animals: ATLA, v. 32, n. 4, p. 437-459, 2004.

GLOBALLY HARMONIZED SYSTEM - GHS. Occupational Safety and Health Administrations: A guide to the GHS of classification and labeling of chemicals. 2005.

GRISHAM, J. W.; SMITH, G. J. Predictive and mechanistic evaluation to toxic responses in mammalian cell culture systems. Pharmacological Reviews, v. 36, Suppl. 2, p. 151S-171S, 1984.

HALLE, W. The registry of cytotocixity: Toxicity testing in cell cultures to predict acute toxicity (LD50) and to reduce testing in animals. Alternative to Laboratory Animals: ATLA, v. 31, n. 2, p. 89-198, 2003.

HALLIWELL, B.; GUTTERIDGE, J. M. C. Free radicals in biology and medicine. $3^{\text {rd }}$ ed. New York: Oxford University Press, 1999.

HOLZHÜTTER, H. G. A general measure of in vitro phototoxicity derived from pairs of dose-response curves and its use for predicting the in vivo phototoxicity of chemicals. Alternative to Laboratory Animals: ATLA, v. 25, n. 4, p. 445-462, 1997.
JAYAPRAKASHA, G. K.; RAO, L. J. Phenolic constituents from lichen Parmotrema stuppeum (Nyl.). Hale and their antioxidant activity. Zeitschrift für Naturforschung. C, Journal of Bioscience, v. 55, n. 11-12, p. 1018-1022, 2000.

LONDERSHAUSEN, M. et al. Molecular mode of action of annonins. Pesticide Science, v. 33, n. 4, p. 427-438, 1991.

LORENZI, H. Árvores brasileiras: manual de identificação e cultivo de plantas arbóreas nativas do Brasil. 2. ed. Nova Odessa: Plantarum, 1992. v. 2.

NATIONAL INSTITUTE OF HEALTH - NIH. Evaluation of In Vitro Cytotoxicity Test Methods: Guidance document on using in vitro data to estimate in vivo starting doses for acute toxicity. 2001. NIH Publication No. 01-4500.

NATIONAL TOXICOLOGY PROGRAM INTERAGENCY CENTER FOR THE EVALUATION OF ALTERNATIVE TOXICOLOGICAL METHODS - NICEATM. Draft background review document: in vitro acute toxicity test methods. 2006.

NATIONAL TOXICOLOGY PROGRAM INTERAGENCY CENTER FOR THE EVALUATION OF ALTERNATIVE TOXICOLOGICAL METHODS - NICEATM. Test Method Protocol: The BALB/c 3T3 neutral red uptake cytotoxicity test: a test for basal cytotoxicity phase III. 2003.

ORGANISATION FOR ECONOMIC CO-OPERATION AND DEVELOPMENT - OECD. OECD Guidelines for the testing of chemicals: Acute oral toxicity - Up-and-down procedure. 2001. Guideline 425.

PETERS, B.; HOLZHÜTTER, H. G. In vitro phototoxicity testing: development and validation of a new concentration response analysis software and biostatistical analyses related to the use of various prediction models. Alternatives to Laboratory Animals: ATLA, v. 30, n. 4, p. 415-432, 2002.

RODRIGUES, V. E. G.; CARVALHO, D. A. Plantas medicinais no domínio dos cerrados. Lavras: Editora da Universidade Federal de Lavras, 2001.

ROESLER, R. et al. Antioxidant activity of A. crassiflora: characterization of major components by electrospray ionization mass spectrometry. Food Chemistry, v. 104, n. 3, p. 1048-1054, 2007a.

ROESLER, R. et al. Atividade antioxidante de frutas do cerrado. Revista Ciência e Tecnologia de Alimentos, v. 27, n. 1, p. 53-60, $2007 \mathrm{~b}$.

ROESLER, R. ET AL. Evaluation of the antioxidant properties of the Brazilian cerrado fruit Annona crassiflora (Araticum). Journal of Food Science, v. 71, n. 2, p. 102-107, 2006.

SEPTÍMIO, L. R. A fitoterapia baseada em ervas medicinais do cerrado. Brasília, DF: Secretaria de Intercâmbio e Projetos Especiais - SIPE, 1994.

SHAHIDI, F. Natural Antioxidants: an overview. Illinois: AOCS Press, 1996.

SILVA, J. A. et al. Frutas nativas dos cerrados. Planaltina: Empresa Brasileira de Pesquisa Agropecuária - EMBRAPA), 1994.

SILVA, S.; TASSARA, H. Frutas no Brasil. 5 ed. São Paulo: Empresa das Artes, 2001.

SPIELMANN, H. et al. The international EU/COLIPA in vitro phototoxicity validation study: results of phase II (blind trial). Part 1: the 3T3 NRU phototoxicity test. Toxicology In Vitro, v. 12, n. 3 , p. 305-327, 1998.

WEINBERG, M. L. et al. Inhibition of drug-induced contractions of guinea-pig ileum by Annona crassiflora seed extract. The Journal of Pharmacy and Pharmacology, v. 45, n. 1, p. 70-72, 1993. 